\title{
Near East in Russian Literary Reflections 1750-1850
}

\section{Kotelnikov Vladimir Alekseevich ${ }^{1}$}

Professor, Institute of Russian Literature (Pushkinskij Dom) of the Russian

Academy of Sciences,

Saint-Petersburg, Russia.

(date of receiving: May, 2019; date of acceptance: October, 2019)

\begin{abstract}
This article gives the review examination of some Russian dramatic and poetic works, travel books 1750-1850 containing the reflections of the religious outlook, culture, poetry, national traditions of Near East people. The earliest examples are showing: Afanasij Nikitin's "khozhdenie za tri moria" and "khozhdenija na vostok" by Vasilij Pozniakov, Trifon Korobejnikov; also Ivan Peresvetov's "skazanie o magmetesaltane" and others. The oriental themes and motifs, including Koranical motifs and details of the native nature and the local life, are revealing in the works of M.V. Lomonosov, V.I. Majkov, A.A. Rzhevskij, A.A. Shishkov, V.A. Zhukovskij, P.G. Obodovskij, D.P. Oznobishin, A.S. Griboedov, A.S. Pushkin, A.G. Rotchev, A.D. Illichevskij, L.A. Jakubovich, V.I. Tumanskij, M.Ju. Lermontov, Ja.P. Polonskij, A.N. Majkov, A.K. Tolstoj. There are characteristics of the travel books by V.G. GrigorovichBarskij, D.V. Dashkov, A.N. Muravjev.
\end{abstract}

Keywords: Russian Literature XVIII-XIX, Near East, Oriental Themes and Motifs.

1. E-mail: vladiko@VK9485.spb.edu 


\title{
Ближний Восток в русских литературных отражениях 1750-1850 гг.
}

\section{Котельников Владимир Алексеевич ${ }^{1}$}

Профессор, Институт русской литературы (Пушкинского Дома) Российской

Академии наук,

Санкт-Петербург, Россия.

(дата получения: май 2019 г.; дата принятия: октябрь 2019 г.)

\begin{abstract}
Аннотация
В статье дается обзорное рассмотрение русских драматических и поэтических произведений, путевых записок 1750-1850-х гг., в которых обнаруживаются отражения религиозного миросозерцания, культуры, поэзии, национальных традиций ближневосточных народов. На материале литературы Нового времени показывается присутствие восточных тем и мотивов, в частности, в творчестве М.В. Ломоносова, А.А. Ржевского, В.И. Майкова, а в более поздний период - в произведениях В.А. Жуковского, А.А. Шишкова, А.С. Грибоедова, П.Д. Ознобишина, А.С. Пушкина, А.Г. Ротчева, А.Д. Илличевского, П.Г. Ободовского, Л.А. Якубовича, В.И. Туманского, М.Ю. Лермонтова, В.И. Соколовского. Рассматривается разработка ориентальных мотивов в творчестве А.К. Толстого, Я.П. Полонского, А.Н. Майкова. Речь идет также о путешествиях на Ближний Восток В.Г. Григоровича-Барского, Д.В. Дашкова, А.Н. Муравьева.

Ключевые слова: Русская Литература XVIII-XIX BВ., Ближний Восток, Ориентальные Темы И Мотивы, Поэзия, Драматургия.
\end{abstract}

1. E-mail: vladiko@VK9485.spb.edu 


\section{Введение}

В поле русского культурного и политического интереса Ближний Восток всегда занимал весьма значительное место, начиная со Средневековья до двадцатого века. Ближневосточные темы, в различных их аспектах, возникают уже в летописях, в «Хождении за три моря» Афанасия Никитина, который проходил в Индию через страны Востока, позднее в «Хождениях на Восток» Василия Познякова, Трифона Коробейникова, в текстах Ивана Пересветова («Сказание о Магмете-салтане», XVI в.) и др. Создаются произведения, тематически связанные с Востоком, ранее прошедшие арабскую обработку и в переложениях вошедшие в русскую литературу, - такова, например, «Повесть об Акире Премудром», ассирийский сюжет которой был широко распространен на Востоке. Появляются также тексты, содержащие сведения о военных столкновениях и политических отношениях Запада и Востока, характерны в этом отношении возникшие в русской посольской среде памфлетные сочинения «Переписка турецкого султана с цесарем Леопольдом» и «Переписка турецкого султана с чигиринскими казаками» (последняя четверть XVII в.).

Реальное познавательное освоение Ближнего Востока началось с паломническим движением на Святую Землю, которое, естественно, проходило через разные ближневосточные земли и оставило следы в путевых записках и воспоминаниях. Первопроходцем здесь стал В.Г. ГригоровичБарский, затем в ХІХ в. среди паломников в Святую Землю немало крупных деятелей, получивших широкую известность на государственном, научном и литературном поприщах. Среди них Д.В. Дашков, О.И. Сенковский, А.Н. Муравьев, А.С. Норов, П.А. Вяземский, Н.В. Гоголь, Т.И. Филиппов и многие другие. Их путевые записки замечательны и как историко-документальные источники, и как живые человеческие свидетельства религиозных и умственных настроений эпохи. 
К таким свидетельствам, к извлеченным из книг сведениям в ряде случаев прибавлялся и личный опыт, что, пополняемое художественным вымыслом, в совокупности определяло впоследствии разработку восточной темы в творчестве русских писателей. К ней обращались поэты и прозаики различной тематической и стилевой ориентации, принадлежащие к разным литературным направлениям: М.В. Ломоносов, А.А. Ржевский, В. Майков, позже - В.А. Жуковский, А.А. Шишков, А.С. Грибоедов, А.С. Пушкин, Д.П. Ознобишин, А.Г. Ротчев, А.Д. Илличевский, М.Ю. Лермонтов, В.И. Туманский, А.С. Норов, В.Н. Григорьев, П.Г. Ободовский, А.А. Шишков, В.Г. Тепляков, А. И. Подолинский, В.И. Соколовский, А.Ф. Вельтман, А.К. Толстой, Я.П. Полонский, Л.А. Мей, А.Н. Майков, К.Н. Леонтьев, а в XX в. - И.А. Бунин, Н.С. Гумилев, В.В. Хлебников, С.А. Есенин.

Названные факты присутствия ближневосточных тем и мотивов в русской литературе, разумеется, привлекали внимание исследователей, но преимущественно в своих частных аспектах. Из немногих работ можно назвать статьи В.А. Эбермана «Арабы и персы в русской литературе» (1923), К.С. Кашталевой «Подражания Корану» Пушкина и их первоисточник (1930), В.А. Котельникова «"Восточный вопрос” в русской политике и литературе» (2004), труды Б.М. Данцига («Руские путешественники на Ближнем Востоке»(1965), «Изучение Ближнего Востока в России (XIX - начало XX вв.) (1968), «Ближний Восток в русской науке и литературе (дооктябрьский период)» (1973), а также некоторые работы Т.М. Гольц, Н.Н. Холмухамедовой (связанные, прежде всего, с деятельностью П.Д. Ознобишина). Перечисленные труды учитывались при написании нашей статьи.

\section{Основная часть}

Первоначально для многих русских, отправлявшихся на Ближний Восток, главной целью было посещение Святой Земли, и по дороге к ней они открывали для себя и другие ближневосточные страны. В.Г. Григорович- 
Барский (1701-1747), одержимый жаждой странствий, в 1724 году, в одежде римского пилигрима, отправляется сначала в Европу, после, побывав на Афоне, путешествует по Египту, Палестине; наконец оказывается в Сирии, а с мая 1744 года по 1746 год изучает монастыри и книгохранилища Афона. В течение нескольких лет Григорович-Барский работает над книгой, в которой отразились его впечатления и разыскания (Григорович-Барский 1885). В ней он отчасти следует давней русской традиции паломнических «хожений», но в рамках этого жанра развертывает новый, познавательно более ценный материал - географический, историко-археологический, искусствоведческий. Несравненно полнее, чем в прежних «хожениях», предстает в книге личность автора - пытливого исследователя, знатока языков и культуры, и в то же время православного инока.

Д.В. Дашков (1788-1839) активно участвовал в литературной жизни начала XIX в. вместе с Н.М. Карамзиным, В.А. Жуковским, П.А. Вяземским; затем вступил в дипломатическую службу и был членом русской миссии в Константинополе. Во время русско-турецких столкновений вмешательство Дашкова спасло от гибели множество греков. В 1820 году он путешествовал по Греции и Палестине, что нашло отражение в его путевых очерках, вторая часть которых называется «Русские поклонники в Иерусалиме» (Дашков Кн. 2. 1905). Дашков избегает повторять то, что многократно описано его предшественниками, но не забывает на них сослаться и упомянуть тех, чье мнение он считает более верным. Это касается изображения местности, населения, городской и храмовой архитектуры, расположения святынь, о чем он рассказывает сдержанно, но точно и изящно. Когда же речь заходит о личных впечатлениях при встрече со Святыми местами, он не жалеет слов, исполненных религиозного пафоса и романтической экспрессии.

Известный духовный писатель, а также поэт, драматург, церковный деятель А.Н. Муравьев (1806-1874) - «русский Шатобриан», как называли его 
некоторые современники, - неоднократно бывал на Востоке. Широкую известность принесла ему книга о его первом путешествии туда (Муравьев 1832), предпринятом в 1830 году. Она неоднократно переиздавалась, вызвала множество одобрительных откликов, в том числе и А.С. Пушкина. Описываемый им вид Иерусалима и его окрестностей рождает в душе Муравьева очень сильные движения, в словесной передаче которых автор обычно соединяет литературную манеру романтизма с традицией русского церковного красноречия, которая была близка Муравьеву, прежде всего, благодаря его тесным личным отношениям с митрополитом Московским Филаретом (Дроздовым) - именно Филарет придал данной традиции особенную и новую значительность в своем богословско-проповедническом творчестве. Созерцая с Елеонской горы Соломонов храм, купола храма Св. Гроба, Сион, овраг Геенны, русло Кедрона, долину Иосафатову, вертеп Гефсиманский, он признается: «Я бы желал выразить то необыкновенное волнение, которое овладело духом, когда в одном великом зрелище предстали мне оба Завета: все пророчества Ветхого и их дивное событие в Новом» (Муравьев 1833. 153).

Собственно художественное использование восточных реалий и мотивов начинается с середины XVIII в., в качестве одного из первых примеров чего можно назвать трагедию М. В. Ломоносова «Тамира и Селим» (1750). Сюжет ее представлен как продолжение исторических событий: поражения хана Мамая в Куликовской битве в 1380 г., бегства его в Крым, намерения крымского хана выдать за него свою дочь Тамиру. Дальнейшие события, непосредственно предшествующие сценическому действию, Ломоносов излагает в «Кратком изъяснении»; в нем и тем более в самой трагедии исторические факты уже соединяются с вымыслом: поход багдадского царевича Селима с целью очистить Черное море от крымских разбойников, осада им Кафы, грозящие гибелью коллизии и, наконец, счастливое увенчание любви Тамиры и Селима (Ломоносов 1991. 161-212). Однако принадлежность 
персонажей и происшествий к Востоку еще весьма незначительно сказывается на характерах и стиле трагедии, хотя на Восток прямо указывают топонимика (Малая Азия, Анатолия и др.), исторические фигуры (Хозрой - т. е. иранский шах Хосров I Ануширван).

Более насыщенной восточными реалиями оказалась написанная в 1760-е годы А.А. Ржевским (1737-1804) трагедия «Подложный Смердий»на сюжет, заимствованный из «Истории» Геродота. Действие трагедии происходит в то время, когда трон занимал Лжесмердис, после смерти персидского царя Камбиза, погубившего своего брата Смердиса. С убийством Лжесмердиса разрешается придворная интрига и воцаряется Дарий (Ржевский 1991. 213-266). При сценическом динамизме Ржевский сумел достичь и психологического напряжения в изображении героев, хотя известная условность, продиктованная эстетикой русского классицизма и образцами жанра, которые были узаконены А.П. Сумароковым, здесь очевидна. В этом же русле создавалась трагедия В.И. Майкова «Фемист и Иеронима» (1773), в которой действующими лицами искусно построенного автором сюжета являются турецкий султан Магомет Второй, захвативший Константинополь, его визирь Солиман, под чьим именем и обликом скрывается сын Феодора Комнина, окружение Магомета, и происходит все в султанском серале (Майков 1991. 267-314).

Возникновение в ту пору на русском литературном горизонте Востока как особой темы с более или менее реальным историческим и преимущественно условным жизненным содержанием вполне объяснимо. Во-первых, наличием в культурной памяти представления о необычности и отчасти загадочности экзотических южных стран «за морями и горами», что возбуждало интерес к ним. Во-вторых - открывающейся для образованного светского писателя возможностью изобразить восточных героев и восточную обстановку, из чего извлекался художественный, а в драматургии еще и сценический эффект. 
Главное же - это позволяло вывести персонажей за пределы современной действительности, поставить их в далекой от нее по времени и месту области, где можно приподнять их страсти и поступки до героической высоты, требующейся по законам классицизма. Влияла, конечно, и ближайшая разработка темы в Европе, начиная с П. Корнеля («Родогуна», 1644) вплоть до Вольтера («Заира», 1732; «Магомет», 1739).

Подобные инсценировки на тему Востока, дистанцированные от личного авторского мировосприятия, вскоре ушли из движения литературы, хотя их рецидивы появлялись позже - такова драматическая поэма В.И. Соколовского «Хеверь» (1834-1836), хотя в ней тематическая и локальная приуроченность не составляет цели: колоритное «восточное покрывало» служит скорее для прикрытия ветхозаветного сюжета. Со временем более важным становится личный интерес автора к реальным явлениям, лицам, предметам, связанным с Ближним Востоком, и, соответственно, - включение их в художественную работу.

Поэтическая романтизация Востока во многих случаях была плодом воображения автора, но, разумеется, не обходилась без определенных книжных источников, в том числе ориентальных произведений европейских писателей. Характерный образчик - стихотворение В.А. Жуковского «Песнь араба над могилою коня» (1810), перевод стихотворения французского поэта Ш. Мильвуа «L'arabe au tombeau de son coursier». Отчасти сохраняя свойственную оригиналу стилизацию под древнеарабские «верблюжьи баллады», моаллакаты, Жуковский возвысил тональность своего текста до «героической песни», придавая ему одновременно и элегический оттенок (Жуковский 1999. 153-154). Обращаясь через много лет к теме Востока, Жуковский пишет эпическую поэму «Рустем и Зораб. Персидская повесть, заимствованная из царственной книги Ирана (Шах-Наме)» (1847) (Жуковский 2010. 161-293), бывшую вольным подражанием ближайшему источнику - 
одноименному переложению немецкого поэта Ф. Рюккерта. При этом Жуковский по-своему пытался придать восточный колорит излагаемому им эпизоду о Ростеме и Сохрабе из поэмы Фирдоуси.

В поэзии А.А. Шишкова (1799-1832) восточные мотивы порождаются уже некоторым знакомством с мифологией и историей Востока, возможно, и с какими-то его реалиями, чему способствовало трехлетнее пребывание автора в Грузии. Он удачно вплетает в обращенное к Н.Т. Аксакову стихотворение «Я видел Кур; он катит воды...» (1821) эротические образы гурий, роз Гилани (северная провинция Ирана), он слышит «небесных пери звучный хор» и звуки струн Саади (Шишков 1972. Т. 1. 401-402). В стиле романтического ориентализма написана им баллада «Осман» (1824), в которой изображается потерпевший поражение турецкий султан, скорбящий о своей судьбе среди разрушенного дворца и торжествующих врагов (Шишков 1972. Т. 1. 402-403).

Интерес к Ближнему Востоку, именно к мусульманскому, к его религиозному миропониманию и к поэзии, весьма широко распространился в русской литературе первой половины девятнадцатого века и побудил поэтов разных тематических и стилевых ориентаций к разработке популярной темы.

Необычные для христианина формы изложение религиозных истин, заповедей, пророчеств в священной книге Ислама, ее образный язык вызвали попытки создать поэтические эквиваленты некоторых глав Корана. В 1824 г. Пушкин пишет «Подражания Корану», пользуясь довольно точным русским его переводом, выполненным М.И. Веревкиным в 1790 г. с французского перевода. Он перелагает содержание, зачастую взятое из разных сур, и подчас дополняет его собственным развитием коранических мотивов. Наиболее адекватно передавая образ, найденный в одной из сур, в строфе

\footnotetext{
Земля недвижна; неба своды,

Творец, поддержаны Тобой,
} 
Да не падут на сушь и воды

И не подавят нас собой,

он в своем примечании говорит об источнике: «Какая смелая поэзия!» (Пушкин 1956. 207-214). Через два года к этому жанру обратился и А.Г. Ротчев (1806-1873), стремившийся, под влиянием поэзии декабристов, придать своим подражаниям современный социальный смысл, для чего он выбирал те суры, в которых говорилось о неравенстве людей, о гонениях, о грядущей справедливости (Ротчев 1972. Т. 1. 432-436).

Нередко разработка темы происходила как стилизация действительных или воображаемых произведений восточных поэтов. У Пушкина это стихотворение «Из Гафиза» (1829), написанное в лагере при Евфрате, когда поэт находился вместе с русской армией в Закавказье (Пушкин 1957-а. 119) и когда война, и место действия увлекли его воображение на Восток. Под влиянием других настроений, но в таком же роде написано им в 1835 г. и «Подражание арабскому» (Пушкин 1957-а. 352). Иногда деталь восточного быта пробуждала фантазию и порождали поэтическую реконструкцию былых событий, обстановки, лиц. Так «лирическим героем» стал фонтан в Бахчисарайском дворце хана Крым-Гирея. С ним связаны поэма Пушкина «Бахчисарайский фонтан» (1821-1823) (Пушкин 1957-б. 175-195) и его стихотворение «Фонтану Бахчисарайского дворца» (1824) (Пушкин 1956. 202), а также стихотворение А.Д. Илличевского (1798-1837) «Бахчисарайский дворец» (1827) (Илличевский 1972. Т. 1. 496-497).

Разумеется, гораздо ближе к первоисточникам и гораздо точнее в их русском переводе или переложении были те, кто профессионально занимался восточной культурой. Среди них видное место занимает Д.П. Ознобишин (1804-1877), который с середины 1820-х гг. начинает основательное изучение персидского, арабского языка (а также санскрита) и литературы на этих языках. 
Незаурядные познания в этой области он обнаружил уже в статье 1826 г. «О духе поэзии восточных народов». Однако точность в передаче оригиналов пришла к нему не сразу. С 1826 г. он выбирает формой подражания арабский мауль и создает в этом жанре стихотворения «Час блаженства» (1826), «Долги любви» (1828), «Упрек» (1828), «Счастливая ночь» (1828), в которых довольно приблизительно воссоздает содержание и стиль оригинальных образцов жанра (Ознобишин 2001. Кн. 1. 73, 76, 79, 81). Но вскоре, при прежней свободе поэтического изложения, он начинает в большей степени учитывать содержание и стиль подлинника, создавая такие стихотворения, как «Весна (Подражание Сойюти)», «Фиалка (Из Ибн-Руми)», «Яблоко (Абу-Новас)», «Суетность красоты (Подражание Саади)» (все 1827), «Амулеты. Омар Бен Фаред» (1829), «Ода Гафица» (1829) (Ознобишин 2001. Кн. 1. 144-147, 186, 198-199). Тема продолжается и во вполне оригинальных стихотворениях Ознобишина: «Могаммед» (1829), «Листки поэзии» (1835), последнее посвящено Земзему, священному источнику в Мекке (Там же. 234, 394).

Затронул общий интерес и скромного по своему дарованию поэта Л.А. Якубовича (1805-1839); почерпнутое им из разных источников (в том числе, вероятно, и у Д.П. Ознобишина) представление о Востоке вылилось в романтический панегирик («Иран», 1831), почти целиком состоящий из характерных именований и образов:

Ликуй, Иран! Твоя краса

Как отблеск радуги огнистый!

Земля цветет - и небеса,

Как взоры гурий, вечно чисты!

Так возлюбил тебя Аллах,

Иран, жемчужина Востока, 


\footnotetext{
И око мира, падишах,

Сей лев Ислама, меч Пророка!

Твой воздух амброй растворен,

Им дышит лавр и мирт с алоем;

Здесь в розу соловей влюблен,

Поэт любви томится зноем.
}

(Якубович. 1972. Т. 2. 264)

Подобные картины живописали тогда и другие поэты, в частности П.Г. Ободовский (1803-1864) в «Персидском вечере» (1826), который должен был войти в задуманную «восточную поэму» «Орсан и Леила», отрывки из нее были опубликованы в 1826 г. (Ободовский 1972. Т. 1. 447-448). А Якубович не ограничивался воспеванием Востока, но вслед за Пушкиным и Ротчевым обратился к поэтическим переложениям Корана («Из Алкорана, глава XCI», 1829).

Большую конкретность в деталях, красках, настроении имели произведения, созданные на основании впечатлений, полученных во время пребывания на Востоке. В.И. Туманский (1800-1860) во второй половине 1830-х гг. служил в русском посольстве в Константинополе, что позволяло ему близко узнать и прочувствовать жизнь Востока. Отразился этот опыт в его стихотворении «Дом на Босфоре» (1836) (Туманский 1972. Т. 1. 306-307). В составе русской дипломатической миссии А.С. Грибоедов с 1819 г. находился в Персии, где воспринял чувственное обаяние восточного быта, отразившееся в «Кальянчи (Отрывок из поэмы)» (1821-1822?):

В каком раю ты, стройный, насажден?

Какую влагу пил? Какой весной обвеян?

Эйзедом ли ты светлым порожден,

Питомец Пери, или Джиннием взлелеян? 


\footnotetext{
Когда заботам вверенный твоим

Приносишь ты сосуд водовмещальный

И сквозь него проводишь легкий дым, -

Воздушной пеною темнеет ток кристальный,

И ропотом манит к забвенью, как ручья

Гремучего поток в зеленой чаще!

Чинара трость творит жасминной длань твоя

И сахарныя трости слаще,

Когда палимого Ширазского листа

Глотают чрез нее мглу алые уста...
}

(Грибоедов 1999. 216)

C IX «Подражанием Корану» («И путник усталый на Бога роптал...») Пушкина иногда соотносят балладу «Три пальмы (Восточное сказание)» (1839) М.Ю. Лермонтова (Турбин 1981. 580). В них действительно можно усмотреть противоположные по смыслу аллегорические изображения ближневосточного мира. У Пушкина томившийся жаждой и роптавший на Бога странник находит, наконец, пальму и воду и засыпает возле них, а проснувшись через много лет стариком, видит истлевшую пальму и иссякший источник. Но Аллах вопреки ходу времени совершает чудо: пальма вновь живет, кладезь наполнен водой, к страннику вернулась молодость:

Святые восторги наполнили грудь:

И с Богом он дале пускается в путь.

(Пушкин 1956. 213)

Милостивый и Милосердный дает залог неистребимости жизни и вечного возрождения. 
Лермонтовские «три гордые пальмы» также возроптали на Бога, сетуя на свое бесполезное существование «в песчаных степях аравийской земли». И к ним пришел караван, и пальмы пали под ударами топора и были сожжены в костре. После ухода каравана остался лишь пепел, разносимый ветром, и высыхающий источник.

И ныне все дико и пусто кругом -

Не шепчутся листья с гремучим ключом:

Напрасно Пророка о тени он просит:

Его лишь песок раскаленный заносит

(Лермонтов 1961. 456)

Поэт утверждает мысль о трагической судьбе всего живого: в тварной природе (и, значит, в человеке, который подразумевается в образе пальм, живущих в бесплодной пустыне этого мира лишь по благоволению Бога) пробуждается противление Божьему миропорядку - тогда совершается возмездие и гибельный конец оказывается необратим.

В ином ракурсе и с участием иных сил рисует Лермонтов встречу природы и человека в стихотворении «Спор» (1841). Шат (Эльбрус) предупреждает Казбека о грядущем нашествии людей: «Берегися! Многолюден / И могуч Восток!».

\footnotetext{
- Не боюся я Востока! -

Отвечал Казбек, -

Род людской там спит глубоко

Уж девятый век.

Посмотри: в тени чинары

Пену сладких вин
} 


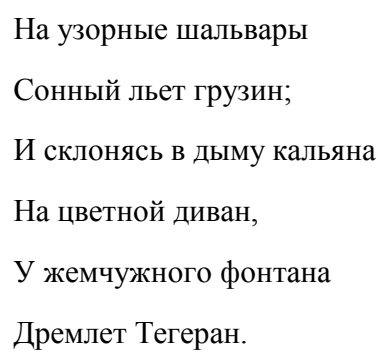

(Там же. 527)

Таким, для распространенного европейского взгляда, предстает здесь Восток в исторической неподвижности и жизненном полусне. Но далее у Лермонтова в сюжете отношений человека и природы взгляд обращается на Север: Казбек различает надвигающуюся оттуда опасность: там

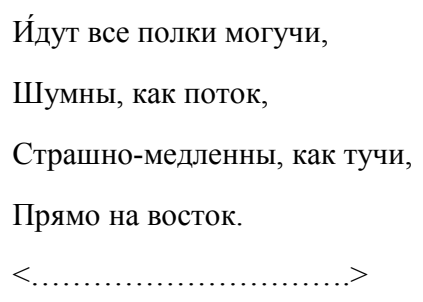

(Там же. 528-529).

Поэт очень широкого тематического кругозора А.Н. Майков (1821-1897) на раннем этапе творчества также обратился к Ближнему Востоку. В небольшой группе стихотворений под общим заглавием «Из восточного мира» выделяется поэтическая стилизация «Молитва бедуина» (1839), в которой правдоподобно передано мировосприятие «человека пустыни» и органично скомпонованы реалии его существования. Нужно заметить, что молитвенное обращение не к Всевышнему, Аллаху, а к солнцу заставляет предполагать, что речь идет об арабе-кочевнике доисламского периода:

О солнце! твой щит вечным золотом блещет А море племен здесь клокочет и плещет... 
Вдали от серебряных рек и ручьев,

Там бродит и гибнет в степи караван позабытый;

Напрасно ждут люди от вихрей песчаных защиты

Под грудью верблюдов и сенью шатров.

О солнце! накрой ты порфирой зеленой

Пустыни нагие; росой благовонной

Кокос наш, и финик, и пальму питай;

Смягчи серебро ты овнов белорунных Кедара;

Верблюдам дай силу идти средь безводья и жара;

Коням легкость ветра пустынного дай!

Самума от нас отврати ты заразы;

А к вечеру звезд сыпь на небе алмазы...

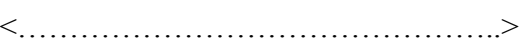

(Майков 1984. Т. 1. 73-74)

Наделенный тонкой художественной отзывчивостью на явления природы, культуры, национальной жизни, Я.П. Полонский (1819-1898) рано обратил свой поэтический взгляд к Ближнему Востоку. Одним из посредников для углубленного проникновения в мир Востока было издание «Les livres sacrés de l'orient», ставшее его настольной книгой в студенческие годы. В книге, наряду с другими текстами Ислама, был и Коран, но с ним Полонский познакомился еще прежде. Под влиянием этого чтения он задумал драматическую поэму «Магомет», в которой, кроме Пророка, намеревался также изобразить, как вспоминал он позже, Абу Талеба, Омара, Кадишо и Айшу. В первой половине 1840-х гг. он написал два стихотворения, которые, вероятно, должны были войти в упомянутую поэму. В первом, «Магомет перед омовением», Полонскому, как мало кому из поэтов той поры, удалось передать мусульманское представление о созданном Аллахом мире (с культовым для 
арабов значением в нем воды) и эсхатологическую картину его земного завершения:

О, благодатная, святая влага!

Со всех сторон,

С востока солнца до заката солнца,

Объемля мир,

Из облаков на жаждущие нивы

Не ты ль дождем

Серебряным, при звуках грома,

Шумишь - как дух,

Когда по воздуху, очам незримый,

Несется он,

По сторонам разбрасывая складки

Своих одежд!

$<\ldots>$

Земля сгорит, и лопнет камень,

И упадут

На рубежах поставленные горы..

Лишь ты одна

Кипящими зальешь волнами

Развалины

Пылающего мира, и густой,

Горячий дым -

Прокатится, гонимый ветром,

Из края в край.

О, благодатная, святая влага!

Обмой меня - 
И освежи меня, и напои

Того, кто жаждет!

(Полонский 1935. 27-28)

Во втором, «Из Корана», с характерно коранической экспрессией, передается Божье повеление Пророку:

Скажи строптивым, малодушным,

Коварно-злым и непослушным,

Что в неразумии своем

Меня слепцы лишь не находят,

И не идут прямым путем,

А ощупью в потемках бродят.

Не спрячут их запоры башен -

Везде найдет их Азраил;

Придет незваный, бледен, страшен -

И изо всех ударит сил...

И вздрогнут каменные стены,

И подогнутся их колены.

(Там же. 28)

Пятилетнее пребывание Полонского в Тифлисе с 1846 г. дало ему, как и другим русским поэтам, оказавшимся на Кавказе и в Закавказье, возможность многое узнать о жизни кавказских мусульман и их единоверцев в закавказских краях. Это нашло отражение в ряде стихотворений, в том числе в «Караване», «отрывке из восточной повести», где автор точно воссоздал черты местного быта и отношений, дал пейзажные зарисовки в восточном стиле: 


\begin{abstract}
Луна светла, как трон Аллы,
Как тени, длинные шагают

Верблюды по краям скалы;

На них ружейные стволы

То пропадают, то мелькают.
\end{abstract}

(Там же. 87)

И еще один любопытный пример - он относится к Крыму и напоминает нам, что со времени политического и культурного освоения Тавриды и Кавказа они традиционно считались «вратами Востока» (поэтому лермонтовские поэмы, действие которых происходило на Кавказе, обычно назывались «восточными повестями», поэтому Бахчисарай был русским «ближним Востоком»).

На материале впечатлений своего крымского путешествия в июне 1856 г. А.К. Толстой (1817-1875) написал цикл «Крымские очерки», в котором есть несколько восточных мотивов. Наиболее очевиден один в начале третьего стихотворения цикла:

Всесильной волею Аллаха,

Дающего нам зной и снег,

Мы возвратились с Чатырдаха

Благополучно на ночлег.

(Толстой 2017. 67)

Мотив вполне оправдан реальностью: в 1850-е гг. Значительную часть коренного населения Крыма составляли татары; они играли существенную роль в сельском хозяйстве; были хорошими проводниками, чем воспользовался Толстой в своем путешествии по Крыму, поэтому типичные 
татарские имена - Гуссейн, Али - естественно появляются в стихотворении. Крымские татары исповедовали ислам, и приведенные стихи передают типично мусульманское упоминание о Боге. Ср. подобное переложение у Пушкина в «Подражаниях Корану» (1824; V):

\footnotetext{
Творцу молитесь; он могучий:

Он правит ветром; в знойный день

На небо насылает тучи;

Дает земле древесну сень.
}

(Пушкин 1956. 210)

Не исключено, что Толстой здесь и в других стихотворениях цикла учитывал аналогичное обращение к мусульманским мотивам в «Крымских сонетах» А. Мицкевича (1826).

\section{Заключение}

В русской литературе 1750-1850 гг. весьма значительной если не по объему, то по распространенности стала тема Ближнего Востока. Она привлекала драматургов XVIII в., разрабатывавших тему еще в русле русского классицизма. Поэты рубежа столетий и первой половины XIX в. творчески преодолевали дистанцию между двумя этнокультурными и этноконфессиональными мирами и в ряде произведений то в форме стилизаций, то с использованием мотивов и реалий жизни ближневосточных народов разрабатывали тему в разных жанрах.

\section{Литература}

1- Грибоедов А.С. (1999). Полное собрание сочинений. В 3 т. Т. 2. СПб.: Изд-во «Нотабене».

2- Дашков Д.В. (1905). Русские поклонники в Иерусалиме. Отрывки из путешествия по Греции и Палестине в 1820 году // Русский архив. 1905. Кн. 2. 
3- Жуковский В.А. (1999). Полное собрание сочинений и писем. В 20 т. Т. 1. М.: Изд-во «Языки русской культуры».

4- Жуковский В.А. (2010). Полное собрание сочинений и писем. В 20 т. Т. 5. М.: Изд-во «Языки русской культуры».

5- Илличевский А.Д. (1972). Бахчисарайский двореи // Поэты 1820-1830-х годов: В 2 т. Т. 1. Л.: Изд-во «Советский писатель».

6- Лермонтов М.Ю. (1961). Собрание сочинений. В 4 т. Т. 1. М.-Л.: Изд-во Академии наук СССР.

7- Ломоносов М.В. (1991). Тамира и Селим // Русская литература - век XVIII: Трагедия. М.: Изд-во «Художественная литература».

8- Майков А.Н. (1984). Сочинения. В 2 т. Т. 1. М.: Изд-во «Правда».

9- Майков В.И. (1991). Фемист и Иеронима // Русская литература - век XVIII: Трагедия. М.: Изд-во «Художественная литература».

10- Муравьев А.Н. (1833). Путешествие ко Святым местам в 1830 г. В 2 ч. 2-е изд. СПб.: Типография III Отделения Собственной Е. И. В. Канцелярии.

11- Ободовский П.Г. (1972). Персидский вечер // Поэты 1820-1830-х годов: В 2 т. Т. 1. Л.: Изд-во «Советский писатель».

12- Ознобишин Д.П. (2001). Стихотворения. Проза: В 2 книгах. М.: Изд-во «Наука».

13- Полонский Я.П. (1935). Стихотворения и поэмы. [М.]: Изд-во «Советский писатель».

14- Пушкин А.С. (1956). Полное собрание сочинений: В 10 т. Т. 2. М.: Издательство Академии наук СССР.

15- Пушкин А.С. (1957-а) Полное собрание сочинений. В 10 т. Т. 3. М.: Издательство Академии наук СССР.

16- Пушкин А.С. (1957-б). Полное собрание сочинений. В 10 т. Т. 4. М.: Издательство Академии наук СССР.

17- Ржевский А.А. (1991). Подложный Смердий // Русская литература - век XVIII: Трагедия. М.: Изд-во «Художественная литература».

18- Ротчев А.Г. (1972). Подражания Корану // Поэты 1820-1830-х годов: В 2 т. Т. 1. Л.: Изд-во «Советский писатель».

19- Толстой А.К. (2017). Полное собрание сочинений и письма. В 5 т. Т. 1. М.: Редакционно-издательский центр «Классика».

20- Туманский В.И. (1972). Дом на Босфоре // Поэты 1820-1830-х годов: В 2 т. Т. 1. Л.: Изд-во «Советский писатель». 
21- Турбин В.Н. (1981). «Три nальмы» // Лермонтовская энциклопедия. М.: Изд-во «Советская энциклопедия». С. 507-508.

22- Шишков А.А. (1972). «Я видел Кур; он катит водығ...»; Осман // Поэты 18201830-х годов: В 2 т. Т. 1. Л.: Изд-во «Советский писатель».

23- Якубович Л.А. (1972). Иран // Поэты 1820-1830-х годов: В 2 т. Т. 2. Л.: Изд-во «Советский писатель».

\section{Bibliography}

1- Griboedov A.S. (1999). Polnoe sobranie sochinenij. V 3 t. T. 2. SPb.: Izd-vo «Notabene».

2- Dashkov D.V. (1905). Russkie poklonniki v Ierusalime. Otryvki iz puteshestvija po Grecii i Palestine v 1820 godu // Russkij arhiv. 1905. Kn. 2.

3- Zhukovskij V.A. (1999). Polnoe sobranie sochinenij i pisem. V 20 t. T. 1. M.: Izdvo «Jazyki russkoj kul'tury».

4- Zhukovskij V.A. (2010). Polnoe sobranie sochinenij i pisem. V 20 t. T. 5. M.: Izdvo «Jazyki russkoj kul'tury».

5- Illichevskij A.D. (1972). Bahchisarajskij dvorec // Pojety 1820-1830-h godov: V 2 t. T. 1. L.: Izd-vo «Sovetskij pisatel'».

6- Lermontov M.Ju. (1961). Sobranie sochinenij. V 4 t. T. 1. M.-L.: Izd-vo Akademii nauk SSSR.

7- Lomonosov M.V. (1991). Tamira i Selim // Russkaja literatura vek XVIII: Tragedija. M.: Izd-vo «Hudozhestvennaja literatura».

8- Majkov A.N. (1984). Sochinenija. V 2 t. T. 1. M.: Izd-vo «Pravda».

9- Majkov V.I. (1991). Femist i Ieronima // Russkaja literatura vek XVIII: Tragedija. M.: Izd-vo «Hudozhestvennaja literatura».

10- Murav'ev A.N. (1833). Puteshestvie ko Svjatym mestam v 1830 g. V 2 ch. 2-e izd. SPb.: Tipografija III Otdelenija Sobstvennoj E. I. V. Kanceljarii.

11- Obodovskij P.G. (1972). Persidskij vecher // Pojety 1820-1830-h godov: V 2 t. T. 1. L.: Izd-vo «Sovetskij pisatel'».

12- Oznobishin D.P. (2001). Stihotvorenija. Proza: V 2 knigah. M.: Izd-vo «Nauka».

13- Polonskij Ja.P. (1935). Stihotvorenija i pojemy. [M.]: Izd-vo «Sovetskij pisatel'».

14- Pushkin A.S. (1956). Polnoe sobranie sochinenij: V 10 t. T. 2. M.: Izdatel'stvo Akademii nauk SSSR.

15- Pushkin A.S. (1957-a). Polnoe sobranie sochinenij. V 10 t. T. 3. M.: Izdatel'stvo Akademii nauk SSSR. 
16- Pushkin A.S. (1957-b). Polnoe sobranie sochinenij. V 10 t. T. 4. M.: Izdatel'stvo Akademii nauk SSSR.

17- Rzhevskij A.A. (1991). Podlozhnyj Smerdij // Russkaja literatura vek XVIII: Tragedija. M.: Izd-vo «Hudozhestvennaja literatura».

18- Rotchev A.G. (1972). Podrazhanija Koranu // Pojety 1820-1830-h godov: V 2 t. T. 1. L.: Izd-vo «Sovetskij pisatel'».

19- Tolstoj A.K. (2017). Polnoe sobranie sochinenij i pis'ma. V 5 t. T. 1. M.: Redakcionno-izdatel'skij centr «Klassika».

20- Tumanskij V.I. (1972). Dom na Bosfore // Pojety 1820-1830-h godov: V 2 t. T. 1. L.: Izd-vo «Sovetskij pisatel'».

21- Turbin V.N. (1981). "Tri pal'my»// Lermontovskaja jenciklopedija. M.: Izd-vo «Sovetskaja jenciklopedija». S. $50 \tilde{7} 508$.

22- Shishkov A.A. (1972). «Ja videl Kur; on katit vody...»; Osman // Pojety 1820-1830h godov: V 2 t. T. 1. L.: Izd-vo «Sovetskij pisatel'».

23- Jakubovich L.A. (1972). Iran // Pojety 1820-1830-h godov: V 2 t. T. 2. L.: Izd-vo «Sovetskij pisatel'».

\section{HOW TO CITE THIS ARTICLE}

Котельников В. А. (2020). Near East in Russian Literary

Reflections 1750-1850. Issledovatel'skiy Zhurnal Russkogo

Yazyka I Literatury, 8(1), 11-33.

DOI: 10.29252 /iarll.15.11

URL: http://www.journaliarll.ir/index.php/iarll/article/view/106

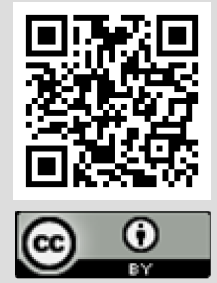




\section{جكيدهاى فارسى}

\section{خاورميانه در آثار ادبى روسيه در فاصله سالهاى •INO}

$$
\begin{aligned}
& \text { ولاديمير الكسيويج كاتلنيكوف' }
\end{aligned}
$$

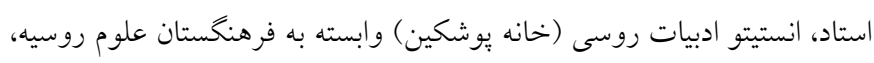

$$
\begin{aligned}
& \text { سن بيتربورى، روسيه. } \\
& \text { (تاريخ دريافت: مه 19.r؛ تاريخ بذيرش: اكتبر 19.19) }
\end{aligned}
$$

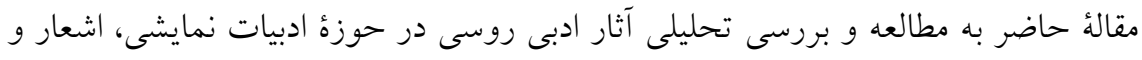

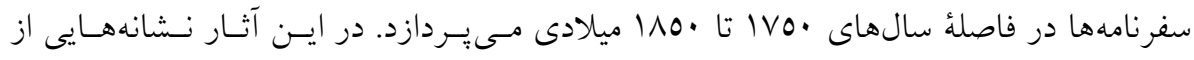

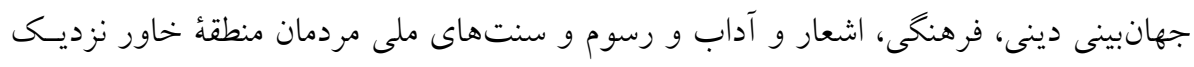

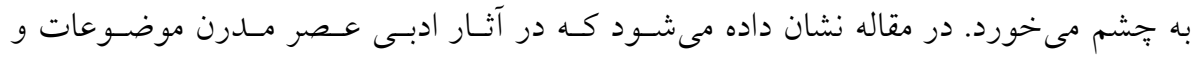

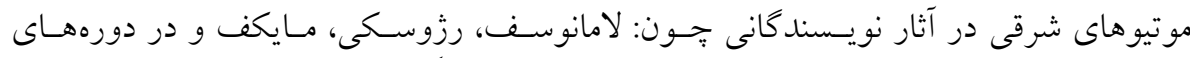

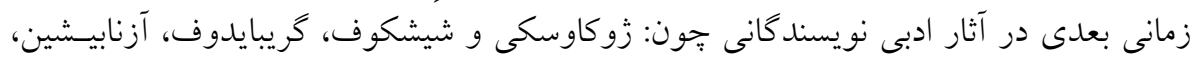

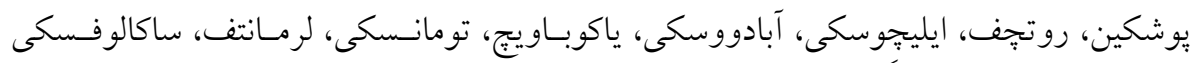

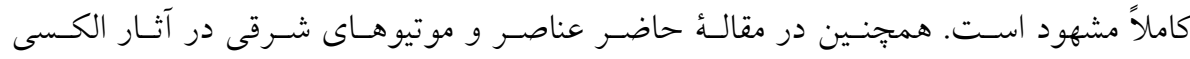

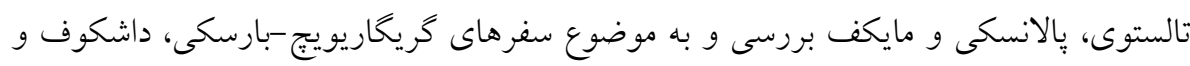

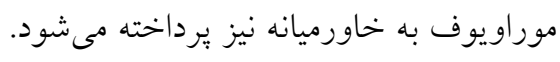

وازگكان كليدى: ادبيات روسيه سده هجدهم و نوزدهم، خاور ميانه، موضوعات و موتيوهاى شرقى، شعر، ادبيات نمايشى و درام. 